Portland State University

PDXScholar

6-9-1989

\title{
The Effect of a Video Presentation and Reference Guide Manual of Helicopter Safety Instruction on the Knowledge Base of Medical Transport Nurses
}

K. Linda Stickney

Portland State University

Follow this and additional works at: https://pdxscholar.library.pdx.edu/open_access_etds

Part of the Educational Methods Commons, and the Nursing Commons Let us know how access to this document benefits you.

\section{Recommended Citation}

Stickney, K. Linda, "The Effect of a Video Presentation and Reference Guide Manual of Helicopter Safety Instruction on the Knowledge Base of Medical Transport Nurses" (1989). Dissertations and Theses. Paper 3915.

https://doi.org/10.15760/etd.5799

This Thesis is brought to you for free and open access. It has been accepted for inclusion in Dissertations and Theses by an authorized administrator of PDXScholar. Please contact us if we can make this document more accessible: pdxscholar@pdx.edu. 
AN ABSTRACT OF THE THESIS OF $\mathrm{K}$. Linda Stickney for the Master of Science in Education presented June 9, 1989.

Title: The Effect of a Video Presentation and Reference Guide Manual of Helicopter Safety Instruction on the Knowledge Base of Medical Transport Nurses.

APPROVED BY THE MEMBERS OF THE THESIS COMMITTEE:

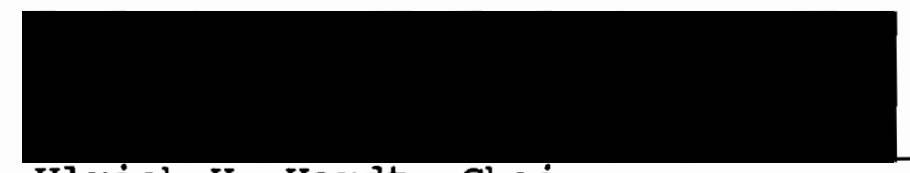

Ulrich H. Hardt, Chair
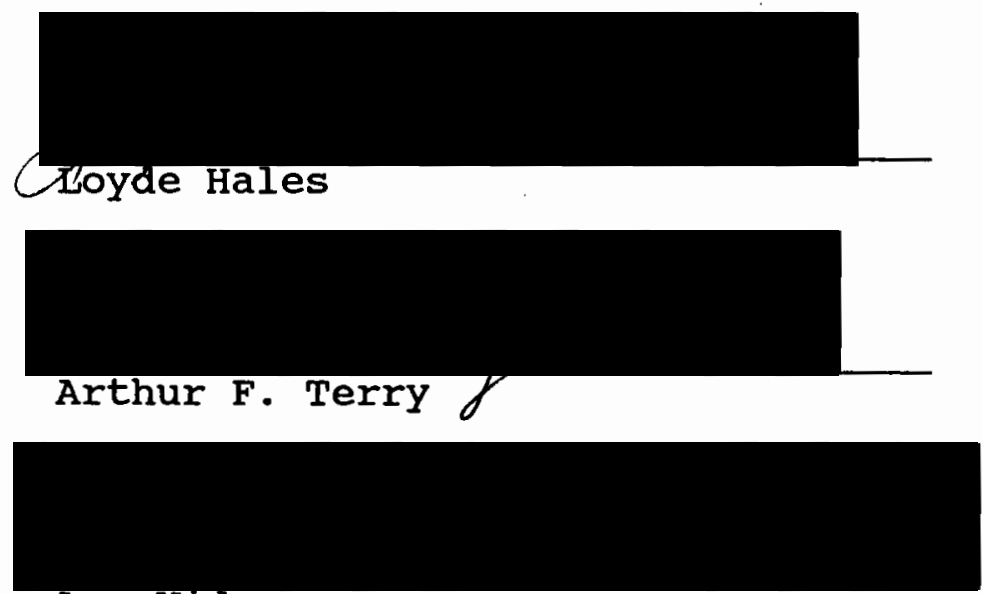

Ann wiamer

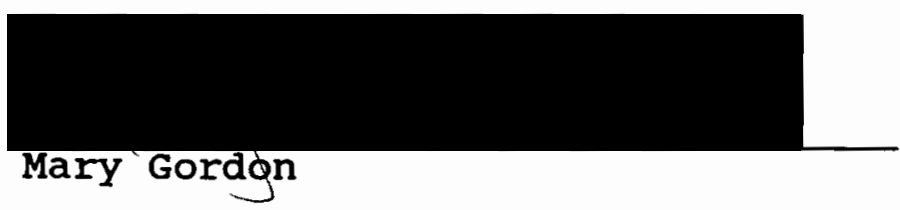

The purpose of this study was to evaluate the results of trained transport nurses being oriented to a new helicopter by a video presentation and reference guide manual 
educational program when compared with trained transport nurses being trained by actual hands-on demonstration. Using a posttest-only design and the $\underline{t}$ test for independent samples, it was found that the two groups of nurses did not differ statistically ( $\underline{t}(9)=0.318, \underline{p}<.051)$. However, since the mortality of the sample subjects was greater than anticipated, the nurses had not flown helicopter transports during the study, and the length of time between the actual demonstration and the posttest being greater than anticipated, it would appear that the results of this study are not conclusive, and further studies are recommended. 
THE EFFECT OF A VIDEO PRESENTATION AND REFERENCE GUIDE MANUAL OF HELICOPTER SAFETY INSTRUCTION ON THE KNOWLEDGE BASE OF MEDICAL TRANSPORT NURSES

by

K. LINDA STICKNEY

A thesis submitted in partial fulfillment of the requirements for the degree of

MASTER OF SCIENCE

in

EDUCATION

Portland state University

1989 
TO THE OFFICE OF GRADUATE STUDIES:

The members of the committee approve the thesis of $K$. Iinda stickney presented June 9, 1989.
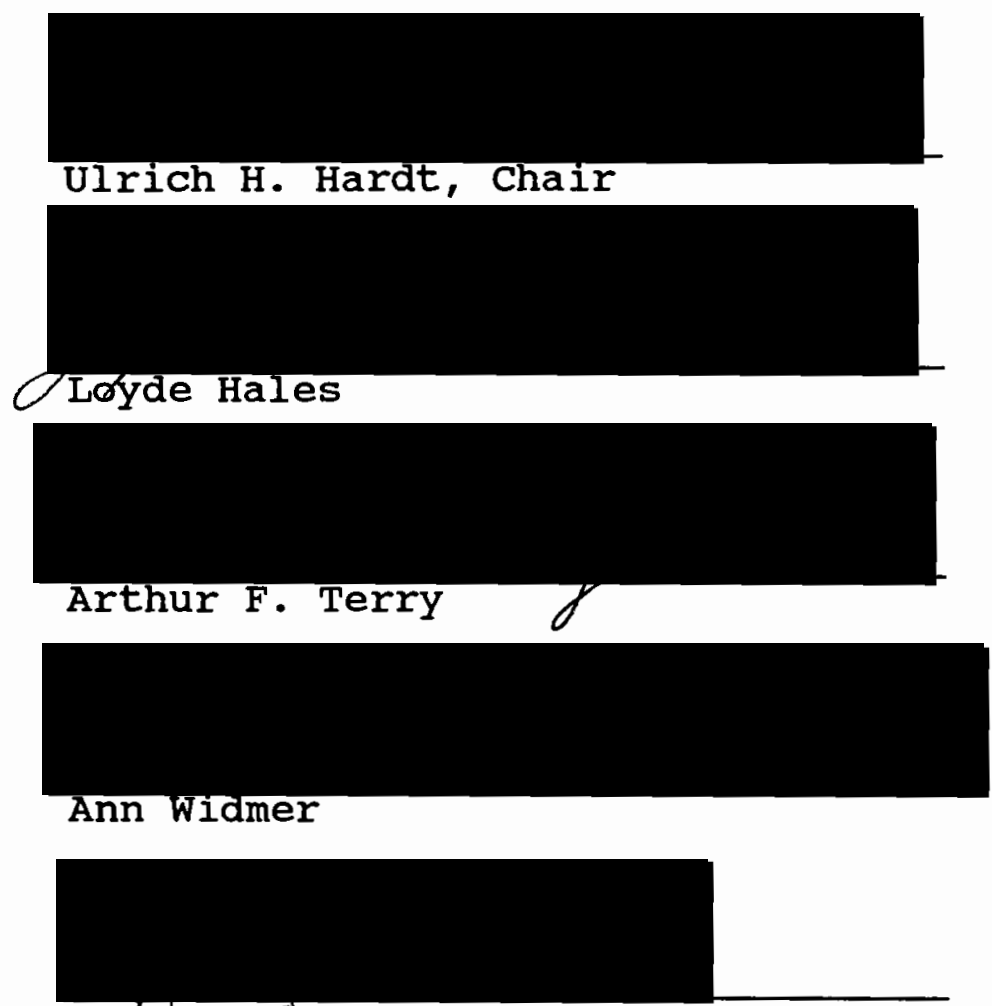

Mary Gordon

APPROVED :

Robert B. Everhart, Dean, school of Education

c. William savery, Ituterim Vice Provost for

Graduate studies and Research 


\section{ACKNOWLEDGEMENTS}

My grateful appreciation is extended to the following people who helped me with this project.

The Portland State University and Concordia College members of my thesis committee:

$$
\begin{aligned}
& \text { Ulrich H. Hardt } \\
& \text { Loyde Hales } \\
& \text { Arthur F. Terry } \\
& \text { Ann Widmer } \\
& \text { Mary Gordon }
\end{aligned}
$$

The oregon Health Sciences University Patient Transport Program Nurse Coordinators:

$$
\begin{aligned}
& \text { Susan Bacon } \\
& \text { Maureen Harrahill } \\
& \text { Kendra Schreiner }
\end{aligned}
$$

My mentor and an Assistant Director of University Hospital: 
TABLE OF CONTENTS

PAGE

ACKNOWLEDGEMENTS . . . . . . . . . . . . . . . . iii

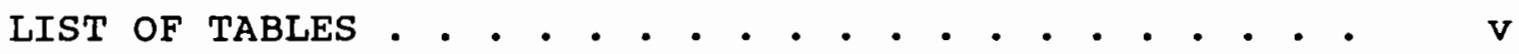

CHAPTER

I INTRODUCTION. . . . . . . . . . . . . . . . 1

statement of Problem. . . . . . . . 2

Statement of Hypothesis . . . . . . . 3

II REVIEW OF THE LITERATURE. . . . . . . . . . . 4

III METHODS AND TECHNIQUES. . . . . . . . . . 11

Subjects. . . . . . . . . . . 11

Instrument. . . . . . . . . . . . . 14

Design. . . . . . . . . . . 15

Procedure ............. . 16

Statistical Analysis. . . . . . . . 17

IV RESULTS . . • . . . . . . . . . . . . 19

$\mathrm{V}$ CONCLUSIONS AND RECOMMENDATIONS . . . . . . 22

Conclusions . . . . . . . . . . 22

Recommendations . . . . . . . . . 23

Summary . . . . . . . . . . . . . 24

REFERENCES . . . . . . . . . . . . . . . . 25

APPENDICES . . . . . . . . . . . . . . . . 27 


\section{LIST OF TABLES}

TABLE

PAGE

I Means, Medians, Modes, and Ranges for Sample Age, Nursing Experience, and Transport Experience. . . . . . .

II Means, Medians, and Ranges for Control

Group: Age, Nursing Experience,

and Transport Experience. . . . . .

III Means, Medians, and Ranges for Experimental

Group: Age, Nursing Experience, and Transport Experience. . . . . . .

IV Posttest Means, Standard Deviations, and $\underline{t}$ for the Educational Materials and Actual Demonstration Groups . . .

V Posttest Means, Standard Deviations, and $\underline{t}$ for the Seven or Less and Eight or Greater Years of Experience . . . . . 
CHAPTER I

\section{INTRODUCTION}

Medical personnel aboard a helicopter historically have not been considered required crew members either by the Federal Aviation Association or by their safety board when an accident occurs. In actual experience, however, medical personnel assist the pilot in areas of observation, communication, and, in extreme emergencies, air control communication, fire abatement, and engine shut-down.

The National Transportation Safety Board safety study of 28 January 1988 stated that:

The Safety Board believes that all medical personnel who routinely fly on EMS helicopter missions need to receive specific training on their functions and duties in the helicopter since they often assume many of the responsibilities of crew members. This training, in addition to their medical training requirements, should address those items required by Part 135.331, Crew Member Emergency Training. This training should also address, as applicable, those areas of responsibility that are non-medical, such as medical personnel and pilot communications, aircraft fuel and systems shutdown, landing zone obstacle avoidance, air traffic avoidance, landing zone safety and radio communications. (United states Government, 1988, p. 33)

When an established transport program acquires the use of a different helicopter, the time and cost involved in training personnel is considerable. In Portland, the in-air rate for a medical helicopter and pilot is $\$ 2,500$ per hour. 
Traditionally, the helicopter pilot would orient the medical transport personnel to the new helicopter in small groups and provide hands-on training to the new equipment as appropriate. When there is a large group of medical transport personnel or several specialty teams, this is an expensive training undertaking, not only in helicopter and pilot costs, but also in medical transport personnel costs.

The use of a video presentation, to provide the educational resource necessary for nurses of an established transport team when the use of a new helicopter is acquired, would be a cost-effective way to meet the necessary training required.

The safety of patient transport is no accident. Careful planning, instruction, and attention to detail is the best insurance for a well prepared and competent medical transport team.

\section{STATEMENT OF PROBLEM}

The purpose of this study was to assess the effectiveness of a video presentation and reference guide manual educational program of helicopter safety on the knowledge base of medical transport nurses. The video presentation was the helicopter safety video prepared by the Nursing Educational Services Department at Oregon Health Sciences University, and the reference guide manual was the oregon Health Sciences University Patient Transport Program 
Helicopter Safety Reference Guide prepared by the Program Administrator and Nursing Coordinators (McBride, stickney, Bacon, Harrahill, \& Shreiner, 1988).

\section{STATEMENT OF THE HYPOTHESIS}

The literature indicates that medical transport personnel need to be knowledgeable about the safety and crew requirements for helicopter transport. A need to establish a cost effective method of training medical personnel of an established transport program is evidenced by the rising costs of medical helicopters. Use of educational materials for training transport nurses would eliminate the payment for helicopter service during the training program. Therefore, it is hypothesized that the helicopter safety knowledge of medical transport nurses trained by a video presentation and reference guide manual educational program will be greater than the knowledge of their peers who have been trained by actual demonstrations. To protect against an adverse finding, the alternate research hypothesis was also entertained; thus, the statistical hypothesis was that the population mean of those trained by demonstration will be equal to those trained by use of educational materials. 


\section{CHAPTER II}

\section{REVIEW OF THE LITERATURE}

The first patient air transport occurred during the Franco-Prussian War in 1870, when wounded soldiers were evacuated from paris using hot air balloons. The military has continued to use air transport medical evacuations. Urdaneta, Miller, Ringenberg, Cram, and Scott (1987) stated:

The military's success in adapting the helicopter to medical evacuation has prompted civilian health care organizations to use similar techniques and equipment in transporting severely injured and critically ill patients. (p. 992)

The number of aeromedical helicopter programs in the United States is growing. Carter, Dolan, Couch, and Coleman (1978) stated:

Their use has been demonstrated to significantly reduce mortality when compared to ground transport. While the issues of their efficacy and even their economic impact have been explored, there exists no information in the medical literature as to their safety. (p. 182)

"The purpose of aeromedical transport must be viewed as much in relation to safety as need. Emergency aeromedical transfer is not without hazard" (Burney \& Fischer, 1986, p. 165). Thomas, Clemmer, Orme, Menlove, and Gibbons (1985) stated:

Despite the rapid growth and the numerous air ambulance services presently [sic] in operation, the "yellow page peril" report of inflight patient 
deaths occurring because of ill-prepared aeromedical transports has left physicians questioning the medical care delivered by flying ambulances. (p. 547)

The American Society of Hospital Based Emergency Air Medical Services (ASHBEAMS) is a voluntary association of hospitals that operate aeromedical programs. Safety is a leading topic for their meetings. At a meeting in 1987, the findings of a report to the safety committee showed that "most fatal accidents occurred at night, in marginal weather, in unfamiliar terrain, and were attributable to pilot error" (Burney, 1987, p. 134).

Timely and appropriate actions can be taken to diminish actual or potential adverse results by utilizing a quality assurance program. The effectiveness of actions taken can then be evaluated. The findings and conclusions from monitoring, evaluating, and problem-solving activities would be documented and shared with the entire patient transport department. Eastes et al. (1988) stated:

A quality assurance program should be used to affirm that the service does meet its goals. It should help to demonstrate the high quality of patient care that is provided on a daily basis, it should provide evidence pointing to the safe conduct of each and every flight. It should provide documentation that the right personnel, aircraft, equipment and training have been brought together to provide a vital service. (p. 14)

The transport team composition will vary depending on the hospital program. In addition to the pilot, a transport nurse, physician, respiratory therapist, and emergency 
medical technician could be members of the medical transport team. Hospital programs can have a primary response system, a secondary response system, or a combination of the two. The primary response system is involved with scene response transports. This system transports patients from scenes of accidents or problem areas to hospitals or designated treatment centers.

The secondary response system provides the interfacility transport of patients. This secondary response program stabilizes the patient before transport and provides tertiary (the highest level of medical expertise) care during transport. Some aeromedical programs advocate a levels approach in defining transport teams. The levels approach defines transports as basic, advanced, or specialized. Thomas, Gibbons, and Clemmer (1986) stated:

Just as the medical needs of the patient vary, so must the capability of the personnel and type of equipment and supplies vary to meet the patient's needs. The utilization of a levels approach provides flexibility in matching patient needs with appropriate levels of care. (p. 704)

A medical transport team can consist of a physician, flight nurse, paramedic, and/or respiratory therapist. When an aeromedical prehospital team is transporting patients with blunt trauma, a study by Baxt and Moody (1987) showed a:

statistically significant reduction in the mortality of patients with blunt trauma treated by a medical helicopter emergency care service staffed by a flight nurse and flight physician could be demonstrated compared with that staffed by a flight nurse and flight paramedic. (p. 3250) 
Medical personnel cannot control, absolutely, the problems of pilot error or mechanical failure; however, they can reduce the risks of potential problems. The problems can be identified through the quality assurance program standards. "A standard can be defined as an achievable model of excellence which is widely accepted and respected" (Eastes et al., 1988, p. 18). The standards can be individualized to address each aeromedical transport program but should incorporate national and state association regulations. The staff can provide expertise in developing standards and providing insight to, not only identifying potential problems, but also to the problem-solving process. Historically, it has been assumed that aeromedical programs provide quality patient care but that quality has not been directly evaluated (Eastes, 1989, p. 75).

In choosing aircraft and pilots, it should be mandatory that they comply with all FAA and ASHBEAMS standards. The medical personnel should be familiar with minimum safety weather standards for helicopter flights. Safety minimums for noise are less easily defined. There are differing views concerning the effects of noise and vibration on medical personnel. A study of the omniflight for saint Joseph Hospital in Omaha concluded "that noise levels are not excessive and neither personal protective devices nor a hearing conservation program are required for our hospital based helicopter service" (Pasic \& Poulton, 1985, p. 508). 
"Transport personnel themselves often suffer from exposure to vibration leading to auditory and visual fatigue, motion sickness, and headache" (Campbell, Lightstone, Smith, Kirpalani, \& Perlman, 1984, p. 969). "Although hearing loss has been shown to be a problem among those working with aircraft, hearing loss and its prevention has not been well studied in aeromedical personnel" (Cook, 1988, p. 70).

Protective clothing is recommended for all personnel. This includes clothing made from natural versus synthetic fibers for fire safety. Carter and O'Brien (1986) stated:

A safety committee within the aeromedical industry has recently been established. The committee consensus indicated "negative image and little substantial benefit from crew helmets, nomex jumpsuits, etc." despite accident survival studies that have demonstrated their benefit in crash survival. ( $p$. 474 )

Shoulder harness restraints are recommended during flight, but if patient care requires releasing seat belts, then "helmets will protect users while working unrestrained during flight" (Gilman, 1987, p. 135).

Medical transport personnel are responsible for knowledge of the aircraft, the loading and securing of the medical equipment, and crowd control until the pilot has secured the helicopter. "One of the major concerns of flight nurses and pilots is the fear that untrained bystanders or emergency care givers will be injured, as a result of carelessness, while working near a helicopter" (Taylor, 1985, p. 327). Medical transport personnel should check the medical 
gas supply and electrical outlets prior to departure and know patient care criteria in the moving environment. "The symptoms of hypoxia are insidious, and nurses are not immune" (Saletta, Behler, \& Chamings, 1984, p. 462).

The medical transport team should know what altitude the aircraft is flying and the maximum altitude for specific medical conditions.

Personnel involved in the transportation of critically ill patients who require ventilatory and oxygenation support must be knowledgeable of oxygen and pressure capabilities of resuscitation bags used in their clinical setting. (Grossbach, 1984, p. 60)

The medical transport personnel must also be responsible for the direction of patient evacuation and emergency procedures during an emergency landing, plus survival techniques. These safety skills can be learned and maintained through an on-going safety program. The philosophy of educational standards for flight nursing as stated by the National Flight Nurses Association (1986) is:

The initial training and continuing education of the flight nurse is essential for the development and maintenance of psychomotor, cognitive and affective skills, thereby enhancing the dynamic quality of flight nursing. (p. 25)

A medical transport personnel safety program would include orientation to the helicopter and flight physiology instruction:

With knowledge of the physiologic stress of flying, an understanding of how that stress might combine with the patient's condition to create problems, and plans for meeting those problems inflight, air transport is safe and efficient. (Saletta, Behler, \& Chamings, 1984, p. 465) 
Safe air transport is not only a moral obligation but also contributes to the economics of health care. Young (1986) stated:

The oil crisis of the late 1970's brought home the fact that our resources are finite. This fact is underlined daily in the health care industry, as we experience a declining inpatient population, rising costs, and the necessity of making hard choices about how dollars will be spent. Thus the issue of distributive justice--how fairly to allocate scarce resources among competing claimants--must be faced. Understood as fairness, justice (in its distributive dimensions) requires that what we cannot do for all, we should do for some only for good reason. Evenhandedness in distributing finite resources is morally expected of us. (p. 237)

Increasing the safety of aeromedical transport through a comprehensive, cost effective educational program for transport personnel should be a high priority. This would increase positive patient outcomes, personnel satisfaction, and economic rewards. 


\section{CHAPTER III}

\section{METHODS AND TECHNIQUES}

\section{SUBJECTS}

The potential pool of subjects for this study was the 28 neonatal nurses in the oregon Health Sciences University Patient Transport Program.

Oregon Health Sciences University includes the schools of Dentistry, Medicine, and Nursing; Vollum Institute for Advanced Biomedical Research; Center for Occupational Disease Research; University Hospital; University Clinics (medical and dental); Doernbecher Children's Hospital; and Child Development and Rehabilitation Center. As a tertiary referral center for the Pacific Northwest and a Level I trauma center for Oregon, University Hospital provides critical care transport by specialty teams.

The Patient Transport Program began in 1972 with the Neonatal Transport Team. In 1979, the Pediatric Transport Team was added, and the Adult Trauma Transport Team started in 1988. Patients are transported to University and Doernbecher Hospitals, as well as to other institutions as a result of a physician referral. Transports are provided for all babies and children, as well as adult trauma victims. 
Patients are transported by ground ambulance, helicopter, and/or fixed-wing aircraft. All vehicles are specially configured to allow intensive care life support during transport. Trained critical-care physicians, specialty trained nurses, and respiratory therapists make up the team, depending on the patient's special needs.

This sample was chosen because it was discovered that after the helicopter orientation demonstration, 14 of the nurses had attended the actual demonstration and 14 nurses had not participated in the demonstration. Reasons for not attending the demonstration included illness, vacations, pregnancy, and staffing.

Due to some of the same events, i.e., vacations, illness, and pregnancy, the total sample was unavailable for participation in this study. Thus, the subjects for this study became a sample $(\underline{n}=11)$ of the above pool of subjects but preserved the integrity of the sample.

Selected biographical characteristics of this sample were examined. For age, in years, the mean, median, mode, and range were $34,34,29$, and 21 , respectively. For years of nursing experience, the mean, median, mode, and range, were $8.7,7.0,7.0$, and 13 , respectively. For years of transport experience, the mean, median, mode, and range were $8.1,6.0,6.0 .$, and 17 , respectively. (See Table I.) 


\section{TABLE I}

MEANS, MEDIANS, MODES, AND RANGES FOR

SAMPLE AGE, NURSING EXPERIENCE,

AND TRANSPORTATION EXPERIENCE

\begin{tabular}{lrrrr} 
Variable & Mean & Median & Mode & Range \\
\hline Age & 34.0 & 34.2 & 29.0 & $26-47$ \\
Nursing Experience & 8.7 & 7.0 & 7.0 & $3-16$ \\
Transportation Experience & 8.1 & 6.1 & 6.0 & $1-18$ \\
\hline
\end{tabular}

The experimental group contained three subjects and the control group contained eight subjects. Selected biographical characteristics of these two groups were compared. For age, in years, the mean, median, and range, of the control group ( $\underline{n}=8)$ were $35,34.5$, and 18 , respectively; compared with 31,29 , and 12 , for the experimental group ( $\underline{n}$ =3). For years of nursing experience, the mean, median, and range, of the control group $(\underline{n}=8)$ were $9,7.5$, and 10, respectively, compared with 7,4 , and 12, for the experimental group $(\underline{n}=3)$. For years of transport experience, the mean, median, range, and scope for the control group ( $\underline{n}$ =8) were 9,6 , and 12 , respectively, compared with 6,1 , and 14, for the experimental group. (See Tables II and III.)

Due to a variety of reasons, including new FAA regulations concerning isolette specifications for helicopters and 
the purchase and design modifications of a new isolette, the sample transport nurses had not participated in a helicopter transport for one year.

\section{TABLE II}

MEANS, MEDIANS, AND RANGES FOR CONTROL GROUP: AGE, NURSING EXPERIENCE, AND TRANSPORT EXPERIENCE

\begin{tabular}{lccc}
\hline Variable & Mean & Median & Range \\
\hline Age & 35 & 34.5 & $29-47$ \\
Nursing Experience & 9 & 7.5 & $6-16$ \\
Transport Experience & 9 & 6 & $6-18$ \\
\hline
\end{tabular}

TABLE III

MEANS, MEDIANS, AND RANGES FOR EXPERIMENTAL GROUP: AGE, NURSING EXPERIENCE, AND TRANSPORT EXPERIENCE

\begin{tabular}{lccc} 
Variable & Mean & Median & Range \\
\hline Age & 31 & 29 & $26-38$ \\
Nursing Experience & 7 & 4 & $3-15$ \\
Transport Experience & 6 & 1 & $1-15$ \\
\hline
\end{tabular}

\section{INSTRUMENT}

A posttest was designed by the researcher in consultation with Dr. Hales to assess the nurses' knowledge of helicopter safety equipment. The test for this project was 
15 multiple choice questions on helicopter anatomy and the location of equipment pertaining to the safety aspects of transport as well as the location of equipment for patient use during flight. The test was reviewed by a representative of the thesis committee and approved by the transport nurse coordinators and the program administrator. A copy of the instrument is found in the Appendix $A$.

\section{DESIGN}

Ideally, the research study would have begun prior to the original orientation training with pretest and nonpretest groups; however, the orientation training had already begun for the group of nurses this study would address.

Fourteen nurses of the Neonatal Transport Team have had an actual helicopter safety demonstration of the new helicopter being used through the sisters of Providence Aircare. The remainder of the neonatal transport nurses were to review the new helicopter safety video and the reference guide after the educational tools had been approved by the Patient Transport Program Standing Committee. The membership of this committee includes the administrator, transport team medical directors, nursing coordinators, respiratory therapy manager and communications director.

The Helicopter Safety Reference Guide (McBride et al., 1988) was developed as a direct result of the preparation of 
a helicopter safety video production. "This reference guide is intended to aid in helicopter safety instruction and review. This guide does not replace helicopter orientation" (p. i). Included in this reference guide are chapters on helicopter anatomy, helicopter equipment and supplies, loading and unloading, and safety, plus an addendum with information on nurses' responsibilities for flight, nursing care in the moving environment, and survival.

Two potential problems to this type of design are time and mortality. The time between the initial actual helicopter safety demonstration and the testing of the nurses was seven and one-half months. This was due to the length of time required to prepare and gain approval for use of the educational materials, and the time required to gain approval of separate committees to proceed with this thesis. Permission letters are found in Appendix B. The mortality of the subjects' availability during the time designated to give the test resulted in an uneven sample of nurses who had the actual demonstration $(\underline{n}=8)$ compared with the nurses who reviewed the educational materials $(\underline{n}=3)$.

\section{PROCEDURE}

On 4 April 1989, six nurses were available to take the posttest. After introductions, this investigator explained that the purpose of the test was to evaluate the results of trained transport nurses being oriented to a new helicopter 
by an actual hands-on demonstration when compared with nurses being trained by educational materials.

The nurses were given two consent forms to sign. One consent form was designed to satisfy the requirements of the Oregon Health Sciences University Committee on Human Research, and the second consent form was designed to satisfy the requirements of the Portland State University Human Subjects Research Review Committee. Copies of the consent forms are found in Appendix $C$.

The nurses were given the helicopter review multiple choice posttest and a copy of the consent forms to keep as prescribed by the oregon Health Sciences University Committee on Human Research. The nurses were thanked for their participation. During the following week, this procedure was followed on an individual basis with five other nurses as availability permitted.

\section{STATISTICAL ANALYSIS}

For age, years of nursing experience, and years of transport experience, means, medians, modes, and ranges were calculated. Means and standard deviations for knowledge of helicopter safety equipment were calculated for the total sample and for various comparison groups--educational materials versus demonstration and nursing experience of those in the demonstration group ( 7 or less years nursing experience versus over 7). Two $\underline{t}$ tests were performed, one for 
each comparison. For each test, the level of significance was set at .05. 
CHAPTER IV

RESULTS

The mean and standard deviation on the knowledge test of helicopter safety equipment were 5.6 and 1.8. The means (and standard deviations) for the educational materials and actual demonstrations groups were $5.7(0.6)$ and 5.6 (2.1), respectively. A $\underline{t}$ test for independent samples was utilized to compare the posttest achievement of the group using the educational materials with the actual demonstration group. It was found that the two means were not statistically different (see Table II). The statistical hypothesis was not rejected $(\underline{t}=.0318, \underline{\mathrm{d} f}=9, \underline{\mathrm{p}}>.05)$.

TABLE IV

POSTTEST MEANS, STANDARD DEVIATIONS, AND

$\underline{t}$ FOR THE EDUCATIONAL MATERIALS AND

ACTUAL DEMONSTRATION GROUPS

Statistic

Group

$\underline{t}$

\begin{tabular}{cc}
\hline $\begin{array}{c}\text { Educational } \\
\text { Materials }\end{array}$ & Actual \\
\end{tabular}

N

3

8

Mean

5.666

5.625

$.0318 *$

Standard Deviation

0.577

2.134

$\star \underline{d f}=9 ; \mathrm{p}<.05$ 
In looking at the data, it appeared that an important variable not previously considered should be explored, thus a secondary question was investigated. For those nurses who participated in the demonstration, is years of nursing experience related to transport safety knowledge following treatment? The research hypothesis was that the mean of the more experienced nurses on the knowledge test administered after the demonstration will be greater than the mean of the less experienced nurses. The alternate research hypothesis was also entertained. Therefore, the statistical results of no difference between population means were the same for the more experienced nurses and less experienced nurses.

For the group of nurses that participated in the actual hands-on demonstration, the mean and standard deviation of those subjects with 8 to 16 years of nursing experience were 7.5 and 0.6 , respectively; for those nurses who had 7 or less years of nursing experience, the mean and standard deviation were 3.8 and 1.0 respectively. A $\underline{t}$ test was performed. The statistical hypothesis was rejected $(\underline{t}=$ $6.708, \underline{\mathrm{df}}=6, \underline{\mathrm{p}}<.05)$. The research hypothesis that the more experienced nurses who participated in a demonstration will demonstrate greater knowledge than those nurses with less nursing experience was accepted. (See Table V.) The data in Table $\mathrm{V}$ are an observation only with no influence on the research of this present project, but it 
indicates an interesting subject that could be researched as a separate study.

\section{TABLE V}

POSTTEST MEANS, STANDARD DEVIATIONS, AND $\underline{t}$ FOR THE SEVEN OR LESS AND EIGHT OR GREATER

YEARS OF EXPERIENCE

Statistic

Group

$\underline{t}$

$\leq 7 \geq 8$

N

4

4

Mean

3.750

7.500

$6.708 *$

standard Deviation

0.957

0.577

* $\underline{\text { df }}=6 ; \underline{p}<.05$ 
CHAPTER V

CONCLUSIONS AND RECOMMENDATIONS

CONCLUSIONS

The statistical hypothesis that the means of those nurses trained by a hands-on demonstration and those trained by educational materials was equal to or greater was not rejected. Therefore, one might be tempted to conclude that the helicopter training of transport personnel could be accomplished with educational materials, since the original hypothesis that the helicopter safety knowledge base of medical transport nurses trained by a video and reference guide educational program will be comparable to or greater than the knowledge base of their peers who have been trained by actual demonstrations was supported. However, there is a fundamental caution in research that the failure to reject a statistical hypothesis does not make it true. Because of the factors described below, this caution is particularly appropriate.

The mortality of the sample subjects was greater than anticipated. While the reasons for this mortality are chance events, it resulted in the actual demonstration group being larger than the educational materials groups, and both 
groups being inadequate in size. The nurses being studied had not flown helicopter transports during the time of the study. Again, this was a chance event, not a predictable occurrence. The length of time between the actual demonstration and the posttest was much longer than optimal. This problem was identified at the time the proposal for this study was presented; however, it was not anticipated to be as great an interval between the actual hands-on demonstration and the test as has occurred.

There is no instrument validity of the test constructed for this study. Comments from the nurses after completing the test suggest that testing on location of equipment may not be valid for this particular group due to the infrequency of the flights. The items in the test are reviewed by the pilots and nurses at the beginning of all transports. It was further suggested that items such as how to approach the helicopter, in what circumstances should you "hot" unload, and crowd control, while basic, are an essential knowledge base for safety and should be tested.

Considering the above factors, it would appear that the results of this study are not conclusive.

\section{RECOMMENDATIONS}

In view of the need for helicopter training of transport nurses and the costs involved, it would appear that a similar study involving a larger sample should be conducted. 
Test/retest studies should be conducted to provide instrument validity. Consideration should be given to the information being requested when constructing the test.

The testing should be accomplished in a more timely fashion. Due to the length of time involved in producing a video presentation, a reference manual with pictures should be considered as an alternative educational resource.

Finally, a study on the length of time of experience and the knowledge base of transport safety should be considered to identify areas of educational support in which the nurses with less experience could gain essential safety knowledge at an accelerated rate.

\section{SUMMARY}

The purpose of this study was to evaluate the results of trained transport nurses being oriented to a new helicopter by a video presentation and reference guide manual educational program when compared with trained transport nurses being trained by actual hands-on demonstration. Using a posttest-only design and the $\underline{t}$ test for independent samples, it was found that the two groups of nurses did not differ statistically $(\underline{t}(9)=0.0318, \underline{p}<.05)$. However, due to variables beyond the scope of this study, the results were non-conclusive and further studies are recommended. 


\section{REFERENCES}

Baxt, W. G., \& Moody, P. (1987). The impact of a physician as part of the aeromedical prehospital team in patients with blunt trauma. Journal of the American Medical Association, 257(23), 3246-3250.

Burney, R., \& Fischer, R. P. (1986). Ground versus air transport of trauma victims: Medical and logistical consideration. Annals of Emergency Medicine, 15(12), 164-168.

Burney, R. (1987). Efficacy, cost, and safety of hospitalbased emergency aeromedical programs. Annals of Emergency Medicine, 16(2), 133-135.

Campbell, A. N., Lightstone, A. D., Smith, J. M., Kirpalani, H., \& Perlman, M. (1984). Mechanical vibration and sound levels experienced in neonatal transport. American Journal of Disabled Children, 138(10), 967970 .

Carter, G., \& O'Brien, D. J. (1986). The impact of aeromedical helicopter programs on emergency medicine resident training: Resident attitudes, perceived risks, and benefits. Journal of Emergency Medicine, 4, 471-476.

Carter, G.L., Dolan, M. C., Couch, R. H., \& Coleman, R. (1978). Safety and helicopter-based programs. Annals of Emergency Medicine, 15(9), 182 .

cook, R. T. (1988). Hearing loss in rotary wing aeromedical service personnel. Aero Medical Journal, $\underline{3}(5), 82-86$.

Eastes, L. E. (1989) . Evaluating the clinical practice of flight nurses: Complexities and innovations. Journal of Nursing Quality Assurance, $\underline{3}(3), 75-83$.

Eastes, L. E., Benson, N., Thomas, F., Leicht, M. , Klein, K. , \& Wynn, J. (1988). Quality assurance in air medical transportation: Guide to effectiveness. salt Lake City: LDS Hospital.

Gilman, J. I. (1987). Carrier and vendor selection. International Anesthesiology clin, 25(2), 117-137. 
Grossbach, I. (1984). Safe transportation of ventilator dependent patients. Critical Care Nurse, $4(3), 59-60$.

McBride, M., Stickney, K., Bacon, S., Harrabill, M., \& Schreiner, K. (1988). Helicopter safety reference guide. Unpublished manuscript. Oregon Health Sciences University, Patient Transport Program, Portland.

National Flight Nurses Association. (1986). Practice standards for flight nurses. Columbia, MO: Waters Printing company.

Pasic, T. B., \& Poulton, T. J. (1985). The hospital-based helicopter. Arch of otolaryngology, 111(8), 507-508.

Saletta, A. L., Behler, D. M., \& Chamings, P. A. (1984). Fit to fly. American Journal of Nursing, 84(4), 462465 .

Taylor, J. E. (1985). Safety at the helicopter landing site: Preventing injuries to emergency personnel and patients. Journal of Emergency Medicine, 11(6), 325327.

Thomas, F., Gibbons, H., \& Clemmer, T. (1986). Air ambulance regulations: A model. Aviation, Space, and Environmental Medicine, 57(7), 699-705.

Thomas, F., Clemmer, T., Orme, J. F., Menlove, R. L., \& Gibbons, H. L. (1985). A nationwide survey of civilian air ambulance service. Aviation, Space, and Environmental Medicine, 56(6), 547-552.

United States Government. (1988). National transportation safety board safety study (NTSB/55-88/01, Access Number PB88-917001). Washington, DC: U. S. Government Printing office.

Urdaneta, L., Miller, B., Ringenberg, B. J., Cram, A. E., \& Scott, D. H. (1987). Role of an emergency helicopter transport service in rural trauma. Archives of Surgery, $122(9), 992-996$.

Young, E. W. (1986). Current ethical issues in emergency care. Journal of Emergency Medicine, $12(5), 235-238$. 
APPENDIX A

POSTTEST 
HELICOPTER REVIEW

Multiple Choice

1. One fire extinguisher is located by the pilot. Where is the second fire extinguisher located?

a. On the port side of the passenger compartment.

b. On the starboard side of the passenger compartment.

c. On the floor under the stretcher.

d. On the back passenger cabin wall near the ceiling.

2. To talk on the Inter Communications System:

a. you need the pilot's permission.

b. the voice activated microphone needs to be close to the lips for correct operation.

c. the head set cord button needs to be depressed.

d. all of the above.

3. Where is the doppler cord located?

a. In the port passenger door pocket.

b. In the starboard passenger door pocket.

c. In port side pack under seat.

d. In velcro pouch on the starboard passenger wall.

4. Where are the Communication system controls (KMA 24) for the flight team located?

a. Above the starboard passenger door.

b. Above the port passenger door.

c. At the aft end of the overhead console.

d. In the rear of the passenger compartment above the auxiliary equipment control panel.

5. To communicate with OHSU Emergency Communications or medical traffic:

a. depress button \#3 on bottom row and set the right hand knob to position 3 .

b. depress top row button \#3 and set right hand knob to position 3 .

c. Depress bottom row button \#2 and set left hand knob to position 2 .

d. Ask the pilot to set the radio controls. 
6. The top row of switches (buttons) on the KMA 24:

a. control the access of the medical team to the pilot, air traffic control, and the hospital.

b. control the external cabin speakers.

c. are only for the pilot's use.

d. are not connected in this unit.

7. Where are the main oxygen valves located?

a. On the starboard passenger compartment wall.

b. On the port passenger compartment wall.

c. In the cargo compartment.

d. On the overhead console.

8. When using oxygen, what source should be used first?

a. Starboard oxygen control valve (FCV 15).

b. oxygen tank under the passenger seats.

c. oxygen tank under the stretcher.

d. Port oxygen control valve (FCV 15).

9. Where are the 110 inverter outlets located?

a. On the port side of the passenger cabin, below the door.

b. On the starboard side of the passenger cabin, below the door.

c. On the floor of the passenger cabin, under the stretcher.

d. On the overhead console.

10. Where are the suction tubing and container 10cated?

a. On the floor of the port side of the helicopter by the passenger door.

b. Under the jump seat.

c. On the floor of the starboard side of passenger cabin, by the passenger door.

d. In the cupboard behind the pilot.

11. Where are the ear protectors for the patient located?

a. In the port passenger door pocket.

b. On the flexible light neck.

c. In the starboard passenger door pocket.

d. In the cupboard behind the pilot. 
12. Where is the emergency locator transmitter (ELT) located?
a. In the compartment above the forward door on the starboard side of the helicopter.
b. In the compartment above the aft door on the port side of the helicopter
c. In the cargo compartment.
d. On the floor console to the left of the pilot.

13. Where is the survival kit located?
a. Under the jump seat.
b. Under the pilot's seat.
c. Under the stretcher.
d. In the cupboard behind the pilot.

14. Where are the power levers, to shut down the engines in case of extreme emergency after landing, located?
a. On the aft most position of the overhead panel.
b. On the forward most position of the floor panel.
c. On the forward most position of the overhead panel.
d. On the aft most position of the floor panel.

15. Where is the rotor brake, used only when the power is off, located?
a. To the right of the power levers.
b. On the floor panel.
c. Near the pilot's door.
d. To the left of the power levers.

Age

Years of transport experience

Years of nursing experience

orientation done by demonstration video Thank you! 
APPENDIX B

PERMISSION LETTERS 


\section{(8) \\ THE OREGON \\ HEALTH SCIENCES UNIVERSITY}

3181 S.W. Sam Jackson Park Road, LiO6, Portland, Oregon 97201 (S03) 279-7784/7887

Research Services

DATE: $\quad$ March 23, 1989

TO: K. Linda Stickney, B.S. UHS-8 Mary MaBride, Advisor

Frof: Wancy White, Administrative fissistant Committee on Human Research, L-106

SUBJECT: Project Title: The Effect of a Video Presentation and Reference Guide Manual of Helioopter Safety Instruction on the Knowledge Base of Medical Transport Nurses.

The above-entitled study falls under category \#1 and is considered to be exermpt from review by the Conmittee on Human Research. Therefore, this study has been put into our exempt files, and you will receive no further conmunication fram the committee concerning this study. If possible, please notify the conmittee when this project has been completed.

If the involvement of human subjects in this study changes you should contact the Cammittee on Human Research to find out whether or not these changes should be reviewed.

If you have further questions regarding the status of this study, please call Nancy white at ext. 7887.

Schools:
Clintcal Pacilities: Unterensity Hospital

Doembecher Memorial Hospital for Cbildren Crippled Cblldren's Division

Outpatient Clinics
Spectal Researcb Diviston:

Valtum institute for

Advanced Blomedical Researcb 


\section{HUMAN SUBJECTS RESEARCH REVIEW COMMITTEE}

\section{MEMORANDUM}

DATE: March 15, 1989

TO: K. Linda Stickney, ED

FROM: Dean Frost, Chairperson

Human Subjects Research Review Committee (HSRRC) 1988-89

RE: HSRRC Approval

In accordance with your request, the Human Subjects Research Review Comittee has revlewed your proposal entitled The Effect of a Video Presentation and Reference Gulde Nanual of Hellcopter Safety Instuction on the Knowledge Base of Medical Transport Personnel for compliance with DHHS policies and regulations on the protection of human subjects.

The committee is satisfled that your provisions for protecting the rights and welfare of all subjects particlpating in the research are adequate and therefore the project is approved. Any conditions relative to this approval are noted below:

None

c: Office of Grants and Contracts

$D F: j m p$ 
APPENDIX C

\section{CONSENT FORMS}




\section{OREGON HEALTH SCIENCES UNIVERSITY}

Consent Form

TITLE. The Effect of a Video Presentation and Reference Gulde Manual of Helicopter safety Instruction of the knowledge Base of Medical Transport Nurseis.

PRINCIPLE INVESTIGATOR. K. LInda Stickney, (503) 279-a187.

PURPose.. The purpose of this test is to evaluate the results of trained transport nurses being orlented to a new helicopter by actual hands on demonstrations versus being tralned by a video presentation and a reference guide manual.

PROCEDURES.. The procedure of evaluation is a written helicopter revlew test.

RISKS AND DISCOMFORTS.. There are no risks or discomforts of participation in this study.

BENEFITS.. Th1s study may help increase knowledge which may benefit others in the future.

ALTERNATE PROCEDURES.. Non-applicable to this study.

CONFIDENTIALITY.. only statistical evidence from this study will be avallable for use. Your name or any other personal

identification is not assoclated with the test.

costs. There are no costs for you to particlpate in this study.

LIABILITY. . The Oregon Health Sclences university, as an agency

of the state, is covered by the state Liability Fund. If you suffer any injury from the research profect, compensation would be avallable to you only if you establish that the injury occurred through the fault of the university, its offlcers or employees. If you have further questions, please call Dr. Michael Balrd at (503) 279-8014.

K. Linda stickney, 279-8187, has offered to answer any questions I may have about the study and what is expected of me In the study. I have been assured that all information I give will be kept confidential and that the ldentity of all subjects w1ll remain anonymous.

I understand that I am free to wlthdraw particlpation in this study at any time without jeopardizing my relationship with Portland state unlversity and oregon Health sclences unlversity. form.

I understand that I w1ll recelve a copy of this consent

Your slgnature below indlcates that you have read the foregoing and agree to particlpate in thls study. 


$$
\text { I, }
$$

I understand the the study Involves taking a Helicopter Review written test.

It has been explained to me that the purpose of this test is to evaluate the results of trained transport nurses beling orlented to a new hellcopter by actual hands on demonstrations versus beling tralned by a video presentation and a reference guide manual.

I may not recelve any direct benefit from participation In this study, but my particlpation may help increase knowledge which may benefit others in the future.

K. Linda stickney has offered to answer any questions I may have about the study and what is expected of me in the study. I have been assured that all information I give will be kept confldential and that the Identity of all subjects will remain anonymous.

I understand that I am free to withdraw participation in this study at any time without jeopardizing my relationship with portland state University and oregon Health sclences university. I have read and understand the foregoing information.

If you experlence problems that are the result of your particlpation in this study, please contact the secretary of the Human subjects Research and Review Committee, offlce of Grants and Contracts, 303 cramer Hall, portland state University, 464-3417. 